\title{
Influence of Wet Micro-Shot Peening on Surface Properties and Corrosion Resistance of AISI 304 Stainless Steel
}

\author{
Xinlong Wei, ${ }^{1, *}$ Dejia Zhu ${ }^{1}$, Xiang Ling ${ }^{2}$, Liang $\mathrm{Yu}^{l}$, Min Dai ${ }^{1}$. \\ ${ }^{1}$ College of Mechanical Engineering, Yangzhou University, Yangzhou 225127, China \\ ${ }^{2}$ School of Mechanical and Power Engineering, Nanjing Tech University, Nanjing 210009, China \\ *E-mail: xlwei@yzu.edu.cn
}

doi: $10.20964 / 2018.05 .30$

Received: 15 January 2018 / Accepted: 27 February 2018 / Published: 10 April 2018

\begin{abstract}
As a new developed shot peening technology, wet micro shot peening is applied to investigate the influence on corrosion behavior of AISI 304 stainless steel in chloride solution using potentiodynamic polarization. Surface modifications including microstructure, residual stress, surface roughness and phase transformation are characterized. Results show that wet micro shot peening can promote the formation of deformation twins and deformation induced martensite, produce grain refinement, generate high magnitude compressive residual stress and increase surface roughness. Results of potentiodynamic polarization curves show that the specimen treated by lower peening pressure has better corrosion resistance than those of higher peening pressure treated and as-received specimen, but the higher peening pressure treated specimen affects inversely on the corrosion resistance with respect to as-received sample. Grain refinement and compressive residual stress induced by shot peening can enhance the corrosion resistance of AISI 304 stainless steel, but the surface roughness and deformation induced martensite generated during shot peening decrease the corrosion resistance. Corrosion resistance of AISI 304 stainless steel in chloride solution depends on the synergy effects of these factors.
\end{abstract}

Keywords: Wet micro shot peening; Microstructure; Surface roughness; Deformation induced martensite; Corrosion resistance

\section{$\underline{\text { FULL TEXT }}$}

(C) 2018 The Authors. Published by ESG (www.electrochemsci.org). This article is an open access article distributed under the terms and conditions of the Creative Commons Attribution license (http://creativecommons.org/licenses/by/4.0/). 